\title{
Development or reflections of the nonprofit sector in Central and Eastern Europe and Hungary
}

\author{
LÁSZLÓ KÁKAI
}

\section{$S$ sciendo}

Politics in Central Europe (ISSN: 1801-3422)

Vol. 16, No. 1S

DOI: $10.2478 /$ pce-2020-0007

\begin{abstract}
The CEE countries are celebrating the 15th anniversary of joining the European Union. The 'feast' is also of note because the EP elections are just in front of us. Instead of weighing up the expected results, we can surmise that the resolution of Central European voters is now weaker in terms of belonging to the European community and their trust in democratic institutions is also considerably lower than it was in the transition era. But what happened? The answer is too complex to be summarised in just one study; the examination of this issue would require a complex analysis of facts from economic transformation to transitions in social and economic subsystems. Of these elements, I wish to introduce the system-level transformation and the current state of civil society.
\end{abstract}

Keywords: nonprofit sector, Central-Eastern Europe, civil society, NGOs

\section{Introduction}

Social sciences have played a considerable and 'creative' role in using the term 'civil society'. This is well summarised in the dissertation written by János Bocz in 2009, in which the author distinguishes between three different types of terminology concerning content and approaches: "In the current terminology, we can see three approaches that lay stress on differing factors in the developed

1 Research for this paper was supported by the following grant: EFOP-3.6.3-VEKOP-16-2017-00007 Young researchers from talented students - Fostering scientific careers in higher education. 
Western countries and in Central Eastern Europe but which are in partial overlap. In the first one, mainly used by social scientists, civil society is an empirical-analytical notion which is used to describe certain forms of social phenomena and social organisations. This ideal typical approach uses the term in order to understand and describe the complex socio-political reality, its origins, development and consequences. The second one is of political-strategic nature and is related to the efforts made to describe what can and what cannot be done in order to reach a political objective. It is in close connection with the existing limitation of power and the relations between state and civil society. As an example, we can mention the politicians who continuously put a limitation on their own power and who promote a transition from an autocratic system into a democratic system. At the same time, we can mention social movements and parties which also use the term 'civil society' as a 'catchword' or to make critiques against current governmental measures, in order to "mobilise" the citizens. In its third meaning, civil society is a normative, philosophical term which is not only used to describe social order but to indicate good society itself" (Bocz 2009: 34). According to this post-fundamentalist interpretation, civil society is characterised by the detachment of governmental and civic institutions, publicity, the diversity of communication media not controlled by the state, legally warranted freedom of civic organisations which allows debates to be conducted, as well as accountability and representation (Keane 2004; Seligman 1992).

In trying to define civil society and civil organisations, all the various universities and international institutions emphasise various factors which do not necessarily represent a scientific understanding but render terms easier to comprehend. According to the definition by the analysts of the London School of Economics (LSE), civil society means the (unlimited) collective activities that are organised along with common interests, aims and values. Theoretically, these institutional forms can be distinguished from market, governmental and household institutional forms but in fact, this picture is very complex and the borders are in many cases unclear and disputed. Civil society includes various social spaces, social stakeholders and institutional forms and these differ a lot in autonomy, social power and the level of institutionalisation. Civil society is often "made of organisations operating as registered charities, NGOs, community groups, womens' organisations, church organisations, professional associations, trade unions, self-help groups, social movements, business associations, alliances and other advocacy organisations."

According to the World Bank's (WB) definition, the term 'civil society' refers to "the non-governmental and nonprofit oriented organisations that actively take part in community life and express the interests and values of their members or

2 Available at: http://www.lse.ac.uk/collections/CCS (18 April 2018). 
others, be those of a moral, cultural, political, scientific, professional, religious or humanistic nature" 3 This interpretation says that civil society stands outside the spheres of family, the state or the market. It does not include those doing for-profit activities but includes the professional- and business- (advocacy) like organisations. Formerly, the WB gave a lot narrower definition of the notion of NGOs and included only the professional, advocacy and nonprofit organisations that supplied services and help in the fields of socio-economic development, the protection of human rights or social care. During recent years - probably not independently from the anti-globalisation movements - the World Bank has accepted trade unions, community-like based organisations, various social movements, religious and charity organisations, educational institutions as well as foundations and other professional associations as civil social institutions and potential partners. ${ }^{4}$ Overall, we may state that, independently from the way the term 'civilness' is interpreted, its social importance can hardly be queried. With no active civil society/organisations, there is no independent or democratic political system and there is nobody to defend citizens against state power, the 'cold reality' of market mechanisms or the toughness of intolerance against otherness.

This study introduces the way Central and Eastern Europe tackled the state socialist past through Hungary's example. How did it deal with its forming civil society? Has civil society been able to form an independent entity within the once politicised state in terms of organisation, embeddedness and national economic importance? Has it remained a respected value within the political power system just as it did during the transition? ${ }^{5}$

\section{System frameworks in brief}

The experts who had carried out international comparative research came to the conclusion that the nonprofit sector is far from being uniform and it takes various forms in each country, according to cultural, historical, political and economic relations (Salamon - Anheier 1999: 34). The typology based on the diversity of social roots (social origin theory) has proved really useful in describing the differences between countries in terms of their nonprofit sectors (volunteering, donation and sector sizes). Based on this survey, the countries were classified into liberal, socio-democratic, corporative and developing systems. ${ }^{6}$

3 Available at: http://web.worldbank.org/WBSITE/EXTERNAL/TOPICS/CSO/0,contentMDK:20101499 me nuPK:244752 pagePK:220503 piPK:220476 theSitePK:228717,00.html (18 April 2018).

4 Available at: http://web.worldbank.org/WBSITE/EXTERNAL/TOPICS/CSO/0,contentMDK:20101499 me nuPK:244752 pagePK:220503 piPK:220476 theSitePK:228717,00.html (18 April 2018)

5 The methodology applied while preparing the study was based on one pillar. It was secondary information collection (desk research), i.e. the elaboration, systemisation and analysation of existing data.

6 - Scandinavian or social democratic model (Sweden, Finland and Norway); - Anglo-Saxon or liberal model (England, Ireland, Canada, Australia and the United States); 
When 'drawing' the analysation frameworks, perhaps the developing systems group seemed the most interesting since this practically included a 'residual' category that integrated several very different countries into one group (Salamon - Sokolowski - Anheier 2000). Thus, CEE countries were included in the developing model together with the poor/étatist countries. At the same time, in case we do not draw a geographical line but examine the post-socialist countries as a merged category, we will be able to make a more precise distinction, namely because of their political (power relations), economic and social situation (e.g. social classes and institutions), as well as their traditions which differ from one another to quite a considerable extent.

The social and economic embeddedness of NGOs varies among nations. The different national traditions and patterns with respect to the positions of government and the market significantly shape the role that nonprofit organisations play. One major factor is the historic patterns of church-state relations. ${ }^{7}$ The type of legal system society uses is also an important (second) factor. ${ }^{8} \mathrm{~A}$ third factor can be described as the influence of the patterns of relationship between government and the third sector is the level of decentralisation of state functions.

The authors of the international comparative research came to the result that the nonprofit sector is not uniformised at all as it represents various forms in each country according to cultural, historical, political and economic circumstances (Salamon - Anheier 1999: 34). The difficulties hiding here are well indicated in Nilda Bullain's experiment which placed the various European nonprofit organisations into an independence ${ }^{9}$ - institutionalisation ${ }^{10}$ matrix on the basis of a survey examining European foundations and regulations.

\section{Central-Eastern European models of the third sector}

The decade preceding the political transition brought about the rebirth and re-exploration of civil society all over the CEE region. The preparation and practical implementation of the transition was to a great extent due to civil movements.

According to the features of the above models, Central-Eastern European countries belong more to the developing model. At the same time, in case the

- Developing or Mediterranean model (Spain, Italy, Portugal and Greece);

- Continental or Corporatist model (Germany, France, Austria and the Benelux States).

7 For examples in The Netherlands.

8 Civil or Roman law tend to be more state-oriented, while common laws are more market-oriented.

9 The place taken on the independence axis shows the level of independence in a political, professional and financial sense, the level of the autonomy of the organisations and the diversification of their income structure.

10 The place taken on the institutionalisation axis depends on the scale of the given sector, the amount of its revenue, the number of its employees, the professionalisation of the organisations and the level to which the sector is able to perform state-welfare functions 
border line is not drawn according to geography and the post-socialist countries are examined as a major category, we can make a much more subtle difference. Owing to their political, economic, social situation and traditions, the post-socialist countries show considerable differences. All this is properly presented in the analysis made by Roland Majlath, who completed Nilda Bullain's survey with useful aspects (Figure 1).

\section{Figure 1: The positions of post-socialist countries in the independence- -institutionalisation matrix}

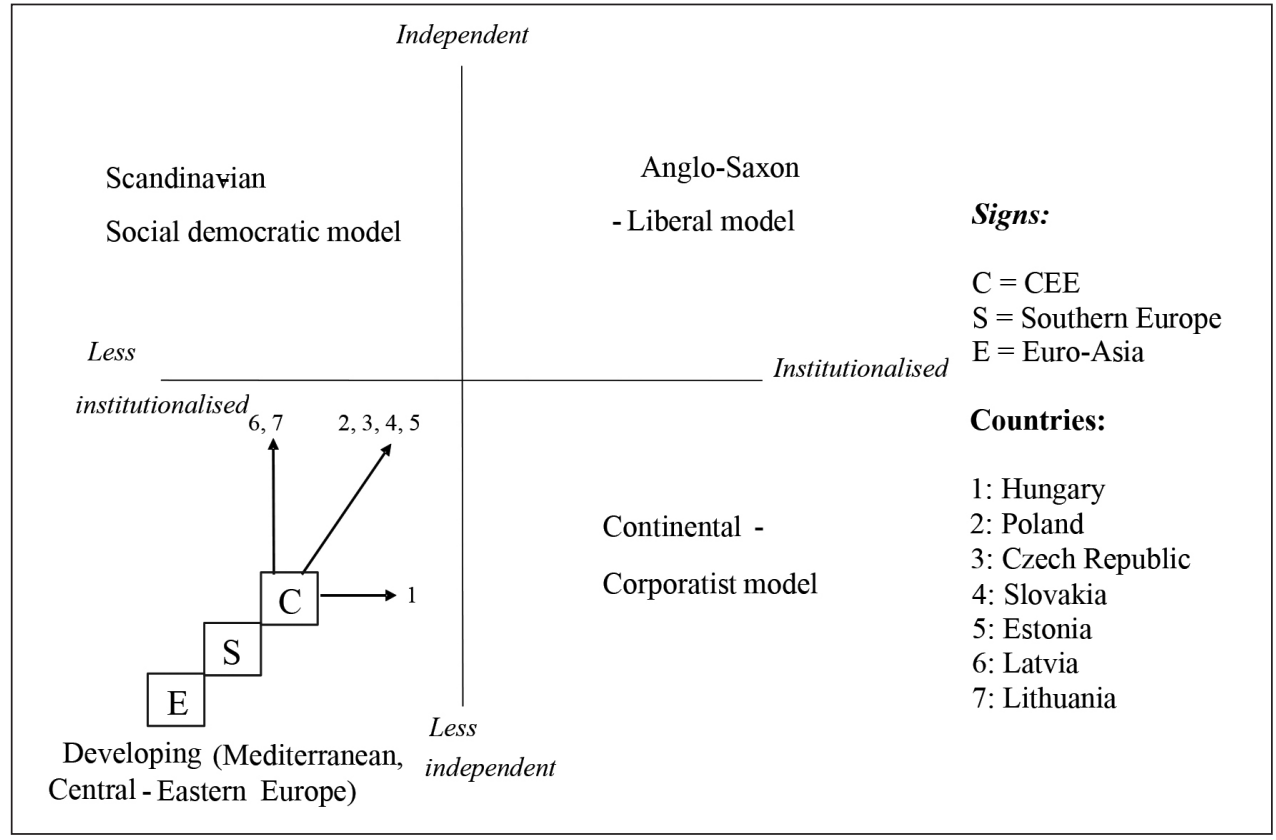

Source: Majláth 2009: 66. Kákai 2016: 75.

So the nonprofit sectors of the CEE countries were deeply affected by the destructive and obstructive effects exerted by the Soviet-like regimes. In Central and Eastern Europe, the development of the nonprofit sector is basically connected to the revolutions of 1989. Except for a short period, civil society was practically destroyed in the communist era. It was only Hungary, Poland and the former Yugoslavia where limited pluralism was allowed at universities and in arts and culture. The renewed appearance of civil society was prepared by the Solidarity movement in Poland, by various small clubs and societies in Hungary and by the peace and green movements in Czechoslovakia (Kaldor - Vejvoda 1997: 20-22). Apparently, the civic sector is at an extremely small scale in these countries (Romania, Bulgaria). It employs only 0.8 percent of the economically active population which is only one tenth of the Western European average. In state 
socialism, the civic sector was in an 'embryonic' state and was only allowed to engage in spare time activities. Time has brought about considerable changes in several fields (education, social care, health care, etc.) since then but these changes are in close connection with the reduction of governmental activity in these areas. Support gained as personal donations make quite a high proportion of the income of the nonprofit sector, while governmental contributions amount to only one third of the Western European average (Salamon - Sokolowski - List 2003: 54). The CEE countries have seen great development.

- The civil sector of each country in the post-socialist region set out from a less institutionalised and less independent position during the transition times; however, the starting point of the three regions - Central Europe, Southern Europe and Euro-Asia ${ }^{11}$ - showed differences. The civil sectors of the Central Eastern European countries had the best initial positions and it is them who have made the biggest step towards the social-democratic, liberal or corporative model.

- The states of Southern Europe compose a mixed group, however, they are similar in being less mobile in the independence-institutionalisation matrix, taking an intermediate position between the civic sectors of the CEE countries and the Euro-Asian region.

- Euro-Asian countries have the most static civic sectors: the region is somewhat odd, even in the Mediterranean (developing) model since in many cases, even the justification of civil organisations is queried by these states.

- Within the different categories of regions, the civil sectors of some countries demonstrate really good performance (Ukraine within Euro-Asia), while in other cases, this is just the other way round (Serbia in Southern Europe) - in the former one, changes were brought about by the 'Orange revolution' and the 'Bulldozer revolution' in the latter (Kákai 2009).

11 This category includes mainly the successor countries from the Caucasian region that were established subsequent to the collapse of the Soviet Union. 
Table 1: Overview of economic data of civil society in the CEE

\begin{tabular}{|c|c|c|c|c|c|c|c|c|c|c|}
\hline & 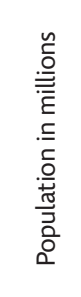 & 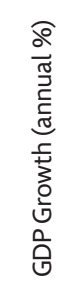 & 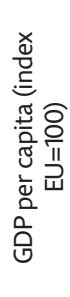 & 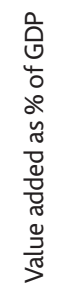 & 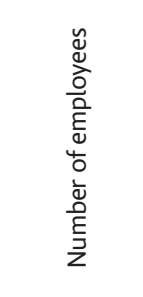 & 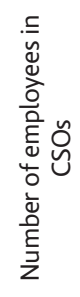 & 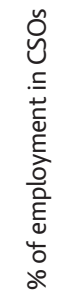 & 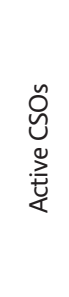 & 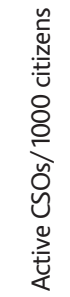 & 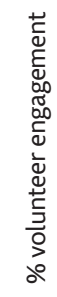 \\
\hline Austria & 8.50 & 0.86 & 127 & 2.20 & $3,600,000$ & 234 & 6.50 & 60 & 7.6 & 27.1 \\
\hline Czech Republic & 10.50 & 4,2 & 85 & 1.77 & $5,023,923$ & 105 & 2.9 & 127,3 & 12.13 & 34.5 \\
\hline Hungary & 9.87 & 2.94 & 68 & 1.55 & $4,550,000$ & 168,35 & 3.70 & 64 & 6.47 & 34.3 \\
\hline Poland & 38.50 & 3.65 & 69 & 1.40 & $16,800,000$ & 151,2 & 0.90 & 80 & 2.8 & 37.0 \\
\hline Slovakia & 5.40 & 3.60 & 77 & 0.98 & $2,200,000$ & 31,9 & 1.45 & 13,4 & 9.70 & 27.5 \\
\hline Croatia & 4.30 & 1.64 & 58 & $\mathrm{n} / \mathrm{a}$ & $2,200,000$ & 34,32 & 1.56 & 57,9 & 13.70 & 8.8 \\
\hline Slovenia & 2.6 & 2.88 & 83 & 2.6 & 820 & 8,364 & 1.2 & 28,6 & 13.90 & 18.0 \\
\hline Bulgaria & 7.60 & 2.97 & 46 & $\mathrm{n} / \mathrm{a}$ & $2,220,000$ & 13,32 & 0.60 & 9,5 & 1.25 & 10.0 \\
\hline Romania & 20.00 & 3.74 & 57 & 0.60 & $4,700,000$ & 56,4 & 1.20 & 26 & 1.30 & 12.8 \\
\hline Albania & 2.80 & 2.56 & 30 & 0.28 & $1,040,000$ & 7,488 & 0.72 & 2,4 & 0.87 & 20.3 \\
\hline $\begin{array}{c}\text { Bosnia \& } \\
\text { Herzegovina }\end{array}$ & 3.80 & 3.16 & 29 & 0.60 & 685 & 2,603 & 0.38 & 6,6 & 1.71 & 7.9 \\
\hline Kosovo & 1.80 & 3.62 & $\mathrm{n} / \mathrm{a}$ & $\mathrm{n} / \mathrm{a}$ & 250 & 6,45 & 2.58 & 8 & 4.44 & 8.0 \\
\hline Macedonia & 2.7 & 3.67 & 37 & 0.96 & 500 & 1,9 & 0.38 & 4,2 & 2.00 & 28.6 \\
\hline Moldova & 3.60 & -0.50 & $\mathrm{n} / \mathrm{a}$ & $n / a$ & $n / a$ & $\mathrm{n} / \mathrm{a}$ & $\mathrm{n} / \mathrm{a}$ & 2 & 0.54 & 18.2 \\
\hline Montenegro & 0.62 & 3.37 & 0.58 & 0.58 & 211 & 781 & 0.37 & 1,1 & 1.69 & 7.3 \\
\hline Serbia & 7.20 & 0.73 & 1.34 & 1.34 & $2,000,000$ & 6,8 & 0.34 & 37,7 & 5.20 & 11.0 \\
\hline
\end{tabular}

Source: Expert Survey 2016.

In Romania, NGOs were generally established within the closed circles of intellectuals. Márton Balogh (2008) speaks about three distinct phases of the democratisation of Romanian society up till now. The period between 1990 and 1996 was a time for the creation of legal frameworks. The number of organisations in the early '90s was around 4,700, which meant app. 62 NGOs per 100,000 inhabitants (Balogh 2008: 57). In the early '90s, the sector was slowly growing (app. 400 organisations per month); it might partly be because of this fact that, in 1997 , the number of officially registered organisations in the non-governmental sector was around 33,000 (Pop 2002: 338.). In the second period, between 1997 
and 2000, the number of organisations kept slowly growing but many of them were not in fact active. Owing to social tensions burdening society, the greatest demand for the activities of the organisations appeared in the fields of social and health care, culture and education. More than 50 percent of the Romanian NGOs were active in these fields (Balogh 2008: 60). Most of the organisations were invisible. The governmental contribution to the sectoral revenue was low (4-5\%), thus the greatest part of the income (60 percent) was gained from international programs and multinational companies settled in the country (Harsányi - Széman 1999: 17). The organisations concentrated mainly in big cities, especially in the capital (Pop 2002: 333). In 2000, the new Romanian Civil Law (No. 26/2000) was passed and it introduced many changes like:

- Easier procedure for founding and registration;

- A more permissive practice allowing associations and foundations to start economic activities;

- A strengthened co-operation between local authorities and NGOs;

- Allowing NGOs to get the status of public interest and public utility (Ba$\operatorname{logh} 2008: 60$ ).

Finally, in the period between 2001 and 2004, the number of organisations reached 40,000. In this period, Act No. 52/2003, which launched the reform of public administration, was passed and by declaring the transparency of public administration, it generated a higher level of participation and activity from international organisations, as well as the Romanian NGOs. The first locally financed program with the decisive contribution of a volunteer organisation was also implemented in this period (Balogh 2008: 63).

In Slovakia, "most of the organisations were established after the transition in 1989. While in 1994 there were 375 registered organisations, this number was 17,000 by 1997" (Bíró 2002: 8). Similarly to the development of the Romanian volunteer sector, that of the Slovakian sector can also be divided into three phases. The 1990s was the decade of the establishment of the governmental structure; 1996 and the following years were the period of structural reforms. In the phase between 2001 and 2005, a kind of 'decentralisation' reform was also implemented (Nemec 2008).

The number of the NGOs kept almost steadily increasing after the early 1990 s. In 2006, there were 26,778 registered organisations and this number grew to more than 40,000 by 2010 (Strečanský 2012). The reason for this growth in number can be explained as the expression of the freedom of uniting and of the citizens' demand to organise which is, in compared to the number of the population in Slovakia (5.4 million), relatively strong. The most frequent type of organisation in Slovakia is the volunteer association, followed by the associations of flat owners and church organisations. 
"The amount of support and donations given by the private sector (thus the financial and non-financial companies and persons) to the nonprofit organisations in a narrower sense (excluding political parties, public legal institutions, etc.) are showing a growing tendency. This amount has been moving between $€ 100$ and 150 million since 2005" (Strečanský 2012: 101).

Each year, approximately 10,000 volunteer organisations get registered on the list of organisations receiving 2 percent tax offers. The 2 percent tax offers are in fact public financing and their utilisation is monitored and controlled by the Supreme Control Committee" (Strečanský 2012: 102).

"The amount of the 2 percentage tax offers received by NGOs was showing a growing tendency for years, however, as a result, the latest two years' financial crisis turned back this tendency and the total offered amount decreased: in 2011, it was $€ 41.5$, which is equal to the 2007 level. 60 percent of the total money comes from ventures and according to the data, the proportion of the ventures is increasing, while that of natural persons is slowly decreasing" (Strečanský 2012: 102).

The most important sources of the public money allocated to nonprofit organisations are the support and grants transferred to the NGOs directly from the budget lines of the ministries and their offices ( $€ 43$ million in 2005 and 51.5 million in 2011). Within governmental support, in 2006, the greatest proportion was allocated to culture, sports and recreation (24 percent); these were followed by professional and employer organisations (14.3 percent), education and culture (9.2 percent) and finally, social (3\%) and health protection (1.9\%). The total revenue of the sector amounted to 1.7 percent of the GDP (Nemec 2008: 121).

Many organisations were active in the social sphere already in the early' 90 s. In 1998, their presence became stronger in the social and health care field and they also played an increasing role in environmental protection, education and culture. The rate of employees by the sector compared to the total number of employees was just a scrap (0.9\%) of the European average (6.9\%) (Salamon Anhier 1999: 61). The volunteer sector was not a substantial employer and its employment potentials have even deteriorated during recent years concerning both full-time and part-time jobs. In 2006, less than 22,000 full-time and 60,000 part-time paid employees worked in the sector. In 2006, the volunteer sector provided 1.1 percent of the GDP (Nemec 2008: 121). The number of full-time workers was 34,000 in 2005 and this number fell to 26,000 by 2010 . The data on volunteering show that the number of volunteers increased, however, the time spent on volunteer work decreased. In the language of numbers, this means that the number of the volunteers grew from 227,000 to 304,000 between 2005 and 2010 but the number of worked hours fell from the 33 million in 2008 to 16 million by 2010 (Strečanský 2012: 104). The most important employers in the third sector are NGOs providing public utility services. They are followed 
by associations and those organisations with church backgrounds. Most of the part-time employees and volunteers work for associations and nonprofit service suppliers (Strečanský 2012: 105).

In the Czech Republic, the development of the nonprofit sector started after the collapse of the one-party system. The birth of the Czech Republic in 1993 created the possibility for the civil sector to revive, however, at first, the government thought this was unnecessary and kept all civic organising suspicious (Pajas 1997: 33). Despite this fact, the citizens' initiations counterbalanced properly the disadvantages arising as a consequence of a centralised state and bureaucracy. In 1996, there were 35,566 registered nonprofit organisations $(28,422$ of them volunteer organisations, 4,514 foundations and 2,630 church organisations) (Pajas 1997: 32). In 2000, their number reached 44,000 and besides them there were almost 4,000 nonprofit organisations owned by the government (Bíró 2002: 9). At present, there are 13 various legal forms existing within the sphere of Czech nonprofit organisations. The numbers are continuously increasing: while there were 70,000 registered organisations in 2005, their number grew to 103,000 by 2009 (Pospíšil - Prouzová - Škarabelová - Tůmová 2012: 26).

The greatest part of the income of Czech nonprofit organisations is provided by government and households and only one tenth comes from business activities. In the referred to years, the rate of direct international financing was negligible. Concerning the rates, this means that in the period between 2005 and $2008,45 \%$ of the sector's revenue came from the government, $44 \%$ was from households (together with volunteer work) and only $1.8 \%$ from abroad. ${ }^{12}$ The newly established foundations are not allowed to use governmental support so these organisations are usually maintained from foreign donations and international projects (Salamon - Anhier 1999: 63).

The environment, having been evolved as a consequence of the global crisis which arrived in the Czech Republic also exerted considerable effects on the sector. Under the threat of the state debt breaking loose and after the elections in 2010, a new centre-right coalition government was formed which passed severe restriction measures and started the reform of public finances, including the welfare system, primarily the pension system and health care. What can now be seen of the changes is that "the draconian restrictions will surely affect the NGOs, first of all those supplying social services” (Pospíšil - Prouzová Škarabelová - Tůmová 2012: 32).

In Poland, the nonprofit sector broke forth with an overwhelming force in the late 1970s, giving space to the efforts of the Solidarity movement. In this process, the collaboration of the formal and informal networks of the secular and church

12 See further data on the web page of the Czech Statistical Office. Available at: http://apl.czso.cz/pll/ rocenka/rocenka.indexnu_sat?mylang=EN). 
organisations, the traditions of the Christian church and the ambitions of independence continuously living in peoples' minds played a considerable role (Arató 1992: 56-65). Concerning the scale of the sector, the available data are contradictory: after the transition, their estimated number was around 30,000 (Okraszewska - Kwiatkowski 2002: 255); others spoke of 47,000 organisations (Les, 1997: 108) but 80,000 was also published (Kaldor - Vejvoda 1997: 21). According to official Polish data, the number of NGOs is around 100,000 today (75 percent of them active). From them, there are 11,000 foundations and 89,000 associations (including 26,000 sports clubs and associations, 16,000 volunteer firemen's associations and 47,000 other organisations) (Przewłocka - Herbst Gumkowska 2012: 60).

The 'condensation picture' of the organisations is geographically varying: 18 percent of all of the working organisations are settled in Warsaw and its environment, 13 percent in South-Poland (mainly in Silesia and the Malopolska region) and more than 5 percent in Northern Poland (Gdansk and environment). In contrast, the rate of the operating organisations remains under 1 percent of the total number in Eastern and South-Western Poland (Okraszewska - Kwiatkowski 2002: 255-256).

The activities of Polish NGOs cover a wide range of fields - they are present in health care, social welfare, culture, human rights, local economy development and environmental protection. Comparing with the number of organisations, the number of employees in the sector is rather low (only 1 percent of the total number of the active population). The reason for this is the relative capital shortage which is also well indicated by the fact that most of the income of the organisations (65 percent) is gained from household and company support. The rate of foreign grants is 15 percent which is completed by a slightly higher state support (20\%) (Les 1997: 110). Owing to this, a growing number of organisations use the support of local municipalities and conclude various types of cooperation contracts with local authority organs (Guc 1999).

The development of the Polish nonprofit sectors is properly introduced in the paper written by Jadviga Przewłocka, Jan Herbst and Marta Gumowska (2012) in which the authors present the growth in the financial potentials of the Polish non-governmental sector during recent years. According to the data by the Central Statistical Office, it doubled between 2005 and 2010 - it was about PLZ 17 billion in 2010 (more than $€ 4$ billion). This is partly a consequence of the substantial growth in support and donations utilised by the biggest Polish NGOs and improvement is at a substantial level only with the biggest organisations. However, the 'average organisations' are also in a better position than they were some years ago with the median of the revenues doubling between 2005 and 2009: the annual PLZ 10,000 in 2005 increased to PLZ 18,000 by 2007 and to PLZ 20,000 (€5000) by 2009. 
Besides the median value, the diversity of income registered in the Polish non-governmental sector is similarly important. "The budget of the 11 percent of the organisations is below PLZ $100(€ 25)$ while the annual revenues of the richest 5 percent are over PLZ 1 million ( $€ 250,000$ ) (this makes up for 75 percent of the total revenue of the sector). During the last decade, this distribution has worsened but in the last two years, this tendency has stopped" (Przewłocka Herbst - Gumkowska 2012: 62).

The Polish authors emphasise the fact that it is not only the nominal value transferred to the organisations that kept continuously growing but also the rate of these amounts within the municipality budgets. According to the authors' opinion, this refers to the fact that the importance of the role played by the organisations in performing public duties has grown. "In 2003, it was only one third of the regions that provided finances for the NGOs at a rate higher than 0.5 percent of their expenditures; in 2010, this rate was 58 percent. The local authorities' increasing contribution to the operation of NGOs is also reflected in the NGOs' budgets. In 2003, 45 percent of the organisations used municipality resources and 51 percent in 2009. Besides, the amount of the allocated money increased as well: in 2003, it was only 16 percent of the disbursements by local municipalities that exceeded PLZ 10,000, while this rate was 27 percent in 2009" (Przewłocka - Herbst - Gumkowska 2012: 68).

There were several factors, primarily from the mid-1980s, that retained growth of the sector at scale. A decisive one of these was that the state preserved its monopoly in the fields of welfare services, education and health care. The excessive governmental control of the sector was well indicated by the fact that the registration of associations and foundations required the permission of the local authority as well.

According to table 1. above, NGOs employ 2 percent of the employees on average (0.9 percent in Poland and 3.7 percent in Hungary) and the contribution of the sector to the GDP is between 0.98 percent (Slovakia) and 1.8 percent (Czech Republic). Concerning organisation density, the data are rather diverse: while in Poland we find 2 operating NGOs per 1000 capita, this number is 12 in the Czech Republic. The rate of budget financing has also changed a lot since the transition. The governmental support of the organisations has considerably grown. In Poland, 55 percent comes from governmental resources and this rate is 65 percent in the Czech Republic, while foreign support has almost totally disappeared. This tendency was present in Hungary, too, until 2010. From that year on, the state support of the NGO sector was radically reduced (form 43 percent in 2010 to 29 percent by 2014; later it increased again to 44 percent by 2017) and the distribution of the grants from the EU structural funds was put under strict governmental control as well (Mayer at al. 2017: 23).

The economic crisis topped this process. Control over and 'colonisation' of civil society grew stronger and stronger, the civil/nonprofit organisations criti- 
cal with and independent of the government were put under growing pressure, their financing was reduced and was centralised. ${ }^{13}$ The political power was practically interchanging between centre-left and centre-right parties. Owing to this permanent 'pendular movement', the attitude of the government in relation to civil society was also continuously changing. Some governments wished to strengthen the role of the state and distrusted civil organisations, while others tried to open doors for them and strived to establish participatory mechanisms in forming their policy.

This process ${ }^{14}$ can be detected in many countries today: it is represented not only by the leading elite of the post-Soviet countries that have been built on the ruins of the former Soviet member republics (Azerbaijan, Tajikistan, Kazakhstan and Armenia) and are traditionally heavily influenced by Moscow; it has been adopted by several Eastern European (Bosnia-Herzegovina, Macedonia), African (Egypt, Ethiopia or Uganda), South-American (Venezuela and Ecuador) and Near-Eastern (Israel) countries and it may reach a breakthrough in a European country, namely Hungary or Poland ${ }^{15}$. Owing to the economic crisis, the situation, however, changed. Right-wing parties gained power in the CEE countries (in 2010 in Hungary, in 2015 in Poland and in 2016 in Slovakia), which brought about a sharp shift in earlier governmental behaviour. Political power is making permanent efforts to bring civil organisations under total control (see the example of Hungary or the state-owned media and the governmental measures taken against the Supreme Court in Poland).

\section{Hungarian models of the third sector}

What can we say of Hungary on the basis of the above examples in a brief and model-like way?

The escalation of the economic, political and social crisis from the mid-80s generated a 'revival' of organisational life in Hungary. At the beginning of the 80 s, new types of social self-organising emerged, from peace movements to eco movements which were later followed by a 'new wave' of student movements,

13 As the harbinger of this, many refer to the start of Vladimir Putin's presidency (2000) since when the Russian authorities have continued to attack the NGOs working for civil and human rights, as well as decreasing their operational authority and have been putting the opposition's movements and the independent media and reporters under pressure.

14 Called the Russian model by many.

15 Beata Szydto announced in November, 2016, that order must be made in the world of NGOs. According to the plans having filtered out, a central governmental office is to be established that will manage the financing of civil organisations itself but we can also mention as an example the fact that the department dealing with human rights defence was fused within the Ministry for Domestic Affairs, the council examining racist attacks was abolished, the financing of the legal centre investigating family violence against women was stopped and the aggravation of the abortion law was put on the agenda again and has been given up by the new Polish government only because of the enormous mass demonstrations. 
self-directing college movements and the club movement within and outside universities, as well as politically-oriented associations and forums. The beginning of the opening was marked by the reappearance of a foundation as a legal entity in 1987, then it went on with the ratification of the Associations Act in 1989 and was concluded with the amendment of the Civil Code (enacted in 1990) which abolished the former restriction that a foundation could only be set up with the approval of the relevant government authority. Following the 1989 Act which guaranteed the conditions of freely setting up organisations, taking advantage of the historical opportunity and the erosion of the political system, the number of organisations was growing continuously (Kákai 2014: 84).

By the late ' 90 s, the border lines of the civil sector became clearly visible and deep changes took place: the organisations got stronger, their economic importance increased and the social legitimacy of the interest groups stabilised.

The development of the Hungarian civil sector can be indicated by three important figures at the macro level: the number of operating organisations, the real value of their income and the number of the employed (Kákai - Sebestény 2012:115-135). Since regular statistical survey started, these values were almost continuously growing until 2008; then, except for employment, the growth in these values decreased and in 2012, each of the three indicators lessened as compared to the previous year. The number of organisations has been decreasing since then - this might be a result of the Act no. CLXXV of 2011 on the right of association, public benefit status and the operation of civil organisations (the Civil Law) that initiated a 'clearing' process within the sector. According to the data of the Central Statistical Office (CSO), after the transition, it was first in 2012 that each of the three indicators moved downwards as compared to the previous year and this tendency continued in 2013. The reduction in the number of organisations was not striking, however, the real value of the sector's revenue decreased by 3 percent and the number of the employed by 11 percent. The rate of the resources gained from governmental support kept on decreasing. In 2013, 35 percent of total sector revenuer came from governmental or municipal budgets which was 5 percent less than the rate in 2012 .

This positive tendency, however, gains another light if we have a look at the real income in terms of one organisation. During nearly twenty years, this figure hardly changed. This means that the growth indicated in the number of organisations and the real income did not appear at the unique organisational level; the previous figure actually 'eliminated' the latter one: the financial situation of an average organisation was the same in 1993 as in 2013 (Kákai - Sebestény 2012: 119).

Owing to the changes within the group of nonprofit enterprises and the spread of public employment within the sector, the tendency in the number of the employees that was continuously growing until 2011 has become hectic during recent years. Employment, however, grew a lot more consistently and 
rapidly. ${ }^{16}$ The nonprofit sector employed almost twice as many people in 2000 and more than three and a half times as many in 2010 as in 1993. Employment, however, is typical within only a narrow range of nonprofit organisations. In 2010 , merely $16 \%$ of them had a paid employee and, within that, only $11 \%$ had a full-time employee. In 2017, the total number of people engaged in the nonprofit sector was 162 thousand. The number of those employed was more than 133 thousand - 91 thousand of which were full time employees, while 42 thousand were part time or not full-time employees.

In 2016, contrary to the 2.5 percent decrease in 2015, the number of those employed in the sector grew by 4.4 percent and by 6.3 percent in 2017 . The real value of the income was continuously growing after 2014; this rate was 14 percent in 2017.

\section{Figure 2: Development of the nonprofit sector: according to number, revenue and employees, 1993-2017}

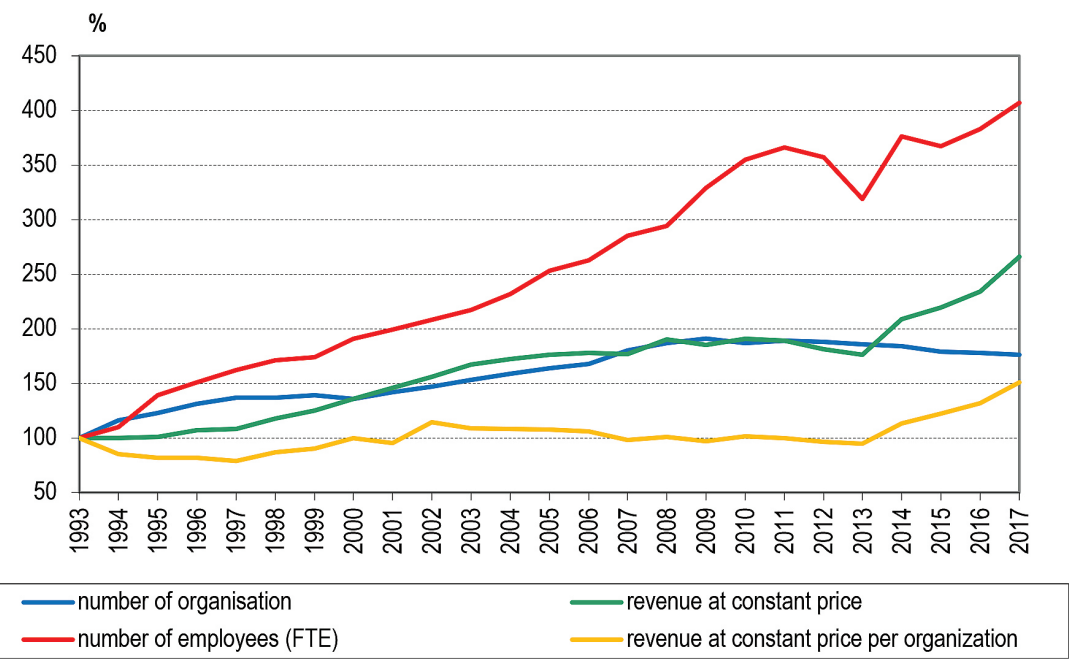

Source: Hungarian Central Statistical Office 2019

The total income for nonprofit organisations as a percentage of GDP had increased by one third between 1993 and 2011 but never reached 5 percent. At the same time, a much more dynamic development was seen in employment: in the very same period, the labour market contribution of the sector grew to three times as much, although remained under 4 percent at all times.

16 In the comparison we use the indicator of the number of staff calculated in terms of regular, full-time employees. This is the Hungarian version of full-time equivalent (FTE) used in the international literature. 
Figure 3: Trends in the national economic contribution of the nonprofit sector, 1993-2017

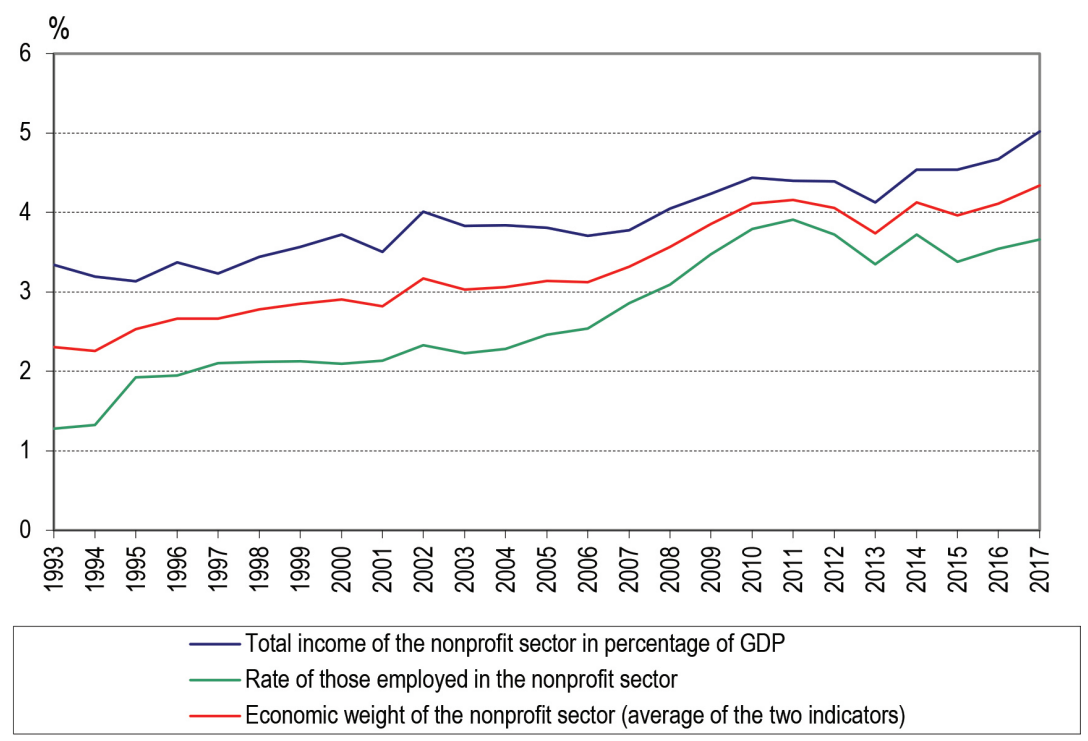

Source: Hungarian Central Statistical Office 2019.

The revenue of the on-profit sector was about HUF 1,924 billion ${ }^{17}$ in 2017. This sum came from four major sources. In 1993, nearly 55\% of the total revenues derived from investment, unrelated business and private donations. By 2013, the form ratio had changed - around $67 \%$ of the total income came from revenue from the basic activity and state support.

The state contributes $42 \%$ to the on-profit sector's income, which is relatively low compared to nearly $60 \%$ of Western European contribution; however, it is regarded high among former socialist countries. I should remark that perhaps the way of financing itself reveals the inherent distortions of the sector (Figure 7.). The income structure, however, considerably changed. In 1993, the bigger part (55\%) of the total income was gained from economic activities and private support. By the late 1990s, this rate considerably changed. From that time on, a growing proportion of the sources were made up of income gained from basic activities and governmental grants. The previous had grown permanently until 2000 and then came a serious recession which was followed by stagnation. The rate of governmental support had remained practically unchanged through long years but began to increase after 2000 and was always above $40 \%$ after 2003; this type of contribution reached HUF 435 billion in $2013 .{ }^{18}$ 


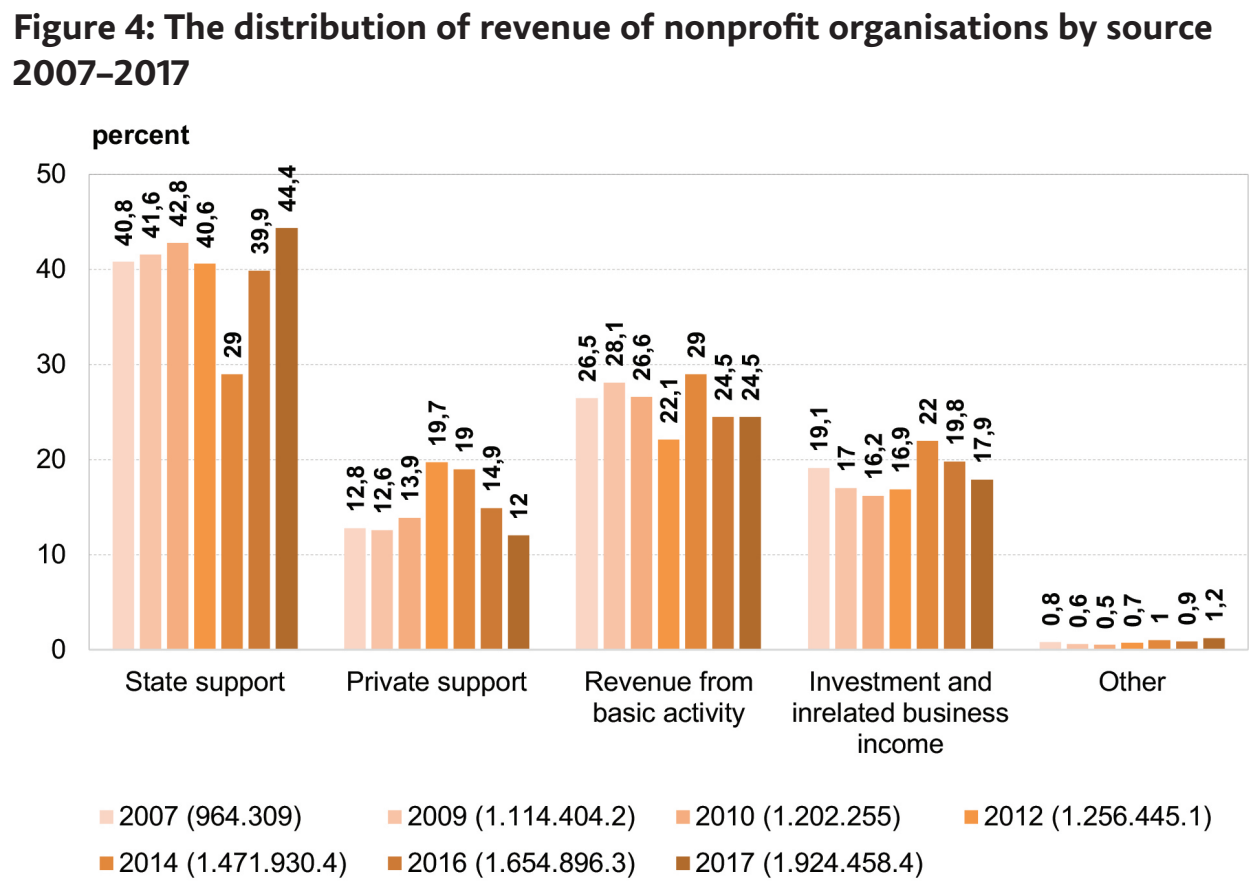

Source: Hungarian Central Statistical Office 1993-2019.

The rate of support from governmental resources considerably increased as compared to that in 2016. 44 percent of total income came from the state or municipal budget which is 4.0 percent higher than last year's data and HUF 194 billion more in numbers. At the same time, own income (from basic activities and management) decreased to 43 percent, so the support indicator ${ }^{19}$ of the sector grew by 1.0 percent as compared to the previous year, i.e., to 56 percent.

Despite all these facts, it is difficult to categorise the Hungarian nonprofit organisations into one of the dimensions mentioned above very explicitly. As Nilda Bullain put it, "the sector mostly takes after itself" (Bullain 2005: 19). One reason for this is that economic and legal regulations in the latest period have in many cases been unconsidered and incoherent. All in all, regarding the facts, we might get a 'picture' showing that Hungarian nonprofit regulations do not follow any of the European models, which in itself should not be a problem; it is not compulsory to join any of the 'lines'. It is, however, a real problem that the prevailing decision makers have practically dealt with regulation of the sector with no concept and no long-term or system-based perspective. Several elements have been taken over from foreign practices, however, this has not been done along a clear concept, so uncertainty deriv-

19 The rate of total (state and private) support in total income. 
ing from the often contradicting regulations has actually been coded into the system (Kákai 2009).

\section{Attack against the free activity of civil organisations in Hungary}

The unfavourable legislative changes adopted between 2011 and 2017 regarding the operation of organisations, as well as the implementation of existing regulations, resulted a degradation of the general legal framework of the sector. ${ }^{20}$ The so-called 'Norwegian Fund Case' should be mentioned at this point as an important phase of government attacks against NGOs financed from abroad (as well). It prepared the government's narrative dividing NGOs into 'good' and 'bad' civil organisations (Glied - Kákai 2017: 25). Already in August, 2013, a communications attack was launched against NGOs partially financed from abroad. They have been called "fake civil organisations" financed from abroad, intervening in politics and the servants of György (George) Soros in the government's communication who are financed from the Hungarian-born billionaire's 'wallet' (Torma 2016: 268-269). In his speech at the 25th Bálványos Summer Free University and Student Camp in Băile Tuşnad (Romania), on 26 July, 2014, Prime Minister Viktor Orbán (explicitly mentioning the 'disputes' related to the Norwegian Fund) stated that these organisations are "political activists paid by foreigners" who intend to "have influence on the state matters of Hungary at the moment, regarding specific questions". ${ }^{21}$ The increasing tension escalated during the summer and autumn of 2014 between the Hungarian government and the Norwegian Fund, the EEA Fund and through them, the NGOs managing the fund. Investigations started against the four found implementer foundations and their 58 guarantors. Representatives of the Hungarian government accused the civil organisations and their leaders of committing criminal acts, with the police and tax authority investigating their cases; the tax authority even suspended their VAT numbers and their offices were searched (Glied - Kákai 2017: 25).

The Norwegian Fund halted its payments to Hungary because the Hungarian government unilaterally changed the domestic implementer body of the entire Norwegian Fund and thus diplomatic relations between Hungarian and Norway also deteriorated. This is when the Hungarian government started to investigate the organisations supported by the civil fund and Hungary received many

20 Sustainability indicators of organisation in 2016 - Hungary. June, 2017. USAID-Ökotárs Alapítvány. Available at: http://okotars.hu/sites/default/files/downloads/civl_szervezetek_fenntrathatosaga_2016. pdf (18 January 2018). Similar processes were witnessed regarding the electoral regulations and the Constitution. See Vörös, 2016.

21 A munkaalapú állam korszaka következik (The era of a work-based state is dawning, speech, Tusványos, 2014) Available at: http://mandiner.hu/cikk/20140728_orban_viktor_a_munkaalapu_allam_korszaka_ kovetkezik_beszed_tusvanyos_2014 (16 January 2018). 
instances of criticism and warnings from its international partners, including the Council of Europe and the United States. A prosecutor ordered the investigation of 7 out of 58 examined organisations, uncovering minor deficiencies. The National Tax and Customs Administration closed its investigation on 20 October, 2015. The investigation was carried out against the organisations for more than a year and it was terminated without revealing any criminal acts (Glied - Kákai 2017).

Instead of cooperating with true non-governmental organisations operating independently from politics, the government has established its own civil hinterland (GONGO - Government Organised NGO) and gave powers to public bodies that carry out funding allocation and distribution activities, clearly distinguishing between activities that can be supported, ought to be supported and may not be supported. The government significantly cut the number of public foundations and instead created and reinforced funds and bodies operating within the state budget such as the Art Fund, the National Cooperation Fund, the Hungarian Olympic Committee and the Hungarian Academy of Arts (Sárközy 2014: 206).

After April, 2016, the government launched new attacks against civil organisations financed from abroad. These include large, Budapest-based NGOs, as well as professionally organised, permanently operated civil organisations with employees, sustained primarily through donations and funding/grant programmes.

Another proof of the process is Act no. LXXVI of 2017 on the transparency of organisations receiving foreign funds. The law qualifies as an "organisation supported from abroad" each association and foundation that was given financial support exceeding HUF 7,200,000 from abroad in the given tax year. Pursuant to this act, in case an organisation reaches this amount, the registering court registers the data of the organisation as "organisation supported from abroad" and sends them to the Minister responsible for the Civil Information Portal who then publishes these data. Then the organisation is obliged to release its 'qualification' on its web page, its programs and its media products. In addition, according to the relevant law, it is obliged to provide a detailed report (including the name of the supporter person or organisation) on each support received from foreign funds exceeding HUF 500,000. The act is in many respects similar to the Russian law, although in Russia, any amount of foreign support must be reported on, according to which the authorities mark the concerned organisation as 'agent'. The regulation passed in Israel in 2016 has similar features as well, although the Israeli regulation does not specify a definite amount like the Hungarian regulation but connects 'qualification' to percentage in the organisational budget (above 50 percent). According to the opinion of the Venice Commission issued on $25^{\text {th }}$ June, 2018, the regulatory measure in issue "lacks the requisite precision", "does not meet the foreseeability criterion as under- 
stood in the ECtHR case-law" and "the provision may result in further arbitrary restrictions to and prohibition through heavy sanctions of the indispensable work of human rights NGOs", not speaking of the fact that "legitimate activities are criminalised under the provision". The summary of the opinion of the Venice Commission is rather clear: "the provision, as examined in the present opinion, infringes upon the right to freedom of association and expression and should be repealed".

There has been sharp criticism worded in the EU in terms of the enactment. In April, 2017, the European Peoples' Party made it very clear that the "NGOs are an integral part of any healthy democracy, that they represent civil society and that they must be respected". This sentence was word by word repeated by EPP spokesman Siegfried Mureșan in 2018 when asked about György Soros' Open Society Foundation leaving Hungary. Both Manfred Weber and Andreas Nick, CDU representative reporting on Hungary, spoke of impassable red lines in this topic. The positions of the NGOs and the right of association have deteriorated since then. Hungary introduced a special tax on immigration which practically means the fully content-based limitation of free speech. According to the Venice Commission, the "unjustified interference with the rights to freedom of expression and of association of the NGOs affected" "will deter potential donors from supporting these NGOs and put more hardship on civil society engaged in legitimate human rights' activities" in the future". The Commission stated that the provision should be repealed.

Several elements of the Hungarian regulation raise perilous questions (Sárközi 2019: 357). On one hand, it violates basic rights and rights principles both at the personal and collective level. Thus, we can mention that the provision contradicts the freedom of opinion and expression, freedom of association, the protection of personal data, the principle of good faith, the protection of good reputation and the prohibition of discrimination. The preamble of the law sets that it is "to see and make see which organisations can be considered as organisations receiving foreign funds"; however, in a statement, an under-secretary made it clear that their intention was not to restrict the organisations explicitly supported from abroad (since the grants received from the EU do not have to be added to the foreign donations in the "qualification process") - the act attacks specifically the NGOs supported by György Soros (Hungarian Civil Liberties Union (TASZ), Transparency International or the Hungarian Helsinki Committee) - the government considers these advocacy organisations fighting for freedom rights, exploring corruption and governmental irregularities and receiving international financial support dangerous. 


\section{Conclusion}

In Europe, we can see the signs of the extension of 'new authorism'. The legal violations and the attacks against independent media and NGOs generated serious international indignation some years ago but similar affairs are now below the threshold of response (Glied 2014).

Changes in the frameworks include changes to the conditions of financing as well. The typical forms of this can be as follows:

- Economic decline, the citizens' impoverishment, reluctance of the rich to widen their donation activities and the slow nature of the spread of CSR may end in the termination of several organisations.

- The mechanisms easing and inciting private donations are lacking, thus private philanthropy remains at a minimal level and the government keeps on supporting its own political allies (NGOs standing close to the government or pseudo-civil organisations).

- In case the current political trend remains unchanged, it will be extremely difficult to keep alive civil organisations that offer alternative services (e.g. in education or health care) for those in need.

- The EU-resources, which are over-bureaucratised and mean a great challenge for the smaller organisations - will become more and more incalculable.

Nonprofit organisations are fighting the same problems in the region: (1) lack of human and financial resources, (2) lack of credibility and (3) a lack of efficient access to the process of policy making.

Mainstream (here: Western) literature sets out from the 'ideal' civil society, i.e. the self-conscious, rational, economically independent citizen who is always ready to participate and defend his/her interests and rights and from the supposition that democratisation initiated from the top or from outside will sooner or later, owing to the natural dynamics of the civil society, become rooted from the bottom and inside as well. In fact, the conditional system of civil society requires a separate exploration. From this, it could become clear that the initial situation of the CEE civil society was drastically different from the ideal model and even the infrastructural development level of the Western civil societies or their degree of supply with resources but the dream of catching up fast pushed reality aside.

In conclusion, Central and Eastern Europe can be expected to remain a very dynamic region in the years to come. In past decades, the region has often been a magnifying glass for international developments and conflicts that have shaped European civil society in general. Some social challenges that are emergent or still dormant in Western European countries have manifested themselves in CEE earlier and with great force, be it the rise of right-wing parties, a lack of public funding, conflicts with partisan media or the development of informal 
civil society structures. One might even speculate that $21^{\text {st }}$ Century Central and Eastern Europe is sometimes ahead in developments that affect civil society in terms of challenges as well as potential solutions to overcome them. To sum up: the weakness of the participation culture in the region, a lack of political civil movements, the closed nature of governance towards civil society and the financial difficulties of the nonprofit sector are the main reasons for which civil society can be less active in promoting 'good governance' and in implementing the social functions that are generally attributed to civil society.

\section{References}

Arató, András (1992): Civil Society and Political Theory. MIT Press, Cambridge, MA.

Balogh, Márton (2008): The role of Romanian NGOs in the democratisation process of the society after 1990. In Osborn, Stephan P. (ed.): The Third sector in Europe. Prospects and Challenges. London: Routledge, 53-66.

Bíró, Endre (2002): Nonprofit szektor analízis. EMLA Egyesület, Budapest.

Bocz, János (2009): A nonprofit szektor strukturális átalakulása Magyarországon. A magyar nonprofit szektor az 1990-es évek elejétől a 2000-es évek közepéig (Doktori disszertáció) Budapest, Corvinus Egyetem, Szociológiai és Társadalompolitikai Intézet, Szociológiai Doktori Iskola. 335.

Bullain, Nilda (2005): Átfogó jogi reformkoncepció: Lépések egy értékalapú civil jövőkép felé. Civil Szemle 1: 5-25

Harsányi, László - Széman, Zsuzsa (1999): Halak és hálók. Nonprofit Kutatások 8. Nonprofit Kutatócsoport-MTA Szociológiai Kutató Intézet, Budapest

Glied, Viktor (2014): From the Green movement to a party. The effect of the crisis and democratic movements in Hungary. In Politeja - Pismo Wydzialu Studiow Miedzynarodowych i Politycznych Uniwersytetu Jagiellonskiego, Issue 28: 31-61.

Glied, Viktor - Kákai, László (2017): Sketch of the Hungarian nonprofit sector after the regime change. Civil Szemle XIV 3: 13-33.

Guc, Michal (1999): Egyedül nem megy - Együttműködési modell nonprofit szervezetek és helyi önkormányzatok között Lengyelországban. Civil Társdalom Fejlődéséért Alapítvány, Budapest.

Kaldor, Mary - Vejvoda, Ivan (1997): Az Európai Unióhoz csatlakozás feltételei: demokratizálás a közép- és kelet-európai országokban. Politikatudományi Szemle, 3. 5-29.

Kákai, László (2009): Kik is vagyunk mi? Civil szervezetek Magyarországon. Pécs, IDResearch Kft. / Publikon Kiadó.

Kákai, László - Sebestény, István (2012): The weight of the nonprofit sector and the impact of the economic crises in Hungary. Civil Szemle IX 3: 115-135.

Kákai, László (2014): Hungarian nonprofit sector twenty years after: the situation of the third sector and impact of the economic crises. Politeja 2(28) Krakkow, 83-113. 
Kákai, László (2016): The main characteristics of Hungarian nonprofit sector after the economic crises In Beata, Pająk-Patkowska - Marcin, Rachwał (ed.): Hungary and Poland in Times of Political Transition. Selected Issues. Poznan: Adam Mickiewicz University Press, Faculty of Political Science and Journalism. 73-84.

Kean, John (2004): A civil társadalom. Typotex, Budapest

Lévai, Katalin - Széman, Zsuzsa (1993): Társadalmi trigonometria. Scientia Humana, Budapest Majláth Roland (2009): A posztszocialista térség civil társadalma. Civil Szemle 3: 53-70.

Meyer, Michael - Moder, Clara Maria - Neumayr, Michaela - Traxler, Nicole - Vandor, Peter (2017): Patterns in Civil Society in Central and Eastern Europe: A Synthesis of 16 Country Reports and an Expert Survey. In Vandor, Peter - Traxler, Nicole - Millner, Reinhard -Meyer, Michael (ed.): Civil Society in Central and Eastern Europe: Challenges and Opportunities. Erste Stiftung Studies, Vienna, 12-41.

Nemec, Juraj (2008): The third sector and the provision of public services in Slovakia. In Osborn, Stephan P. (ed.), The Third sector in Europe. Prospects and Challenges. London: Routledge, 118-133.

Okraszewska, Aldona - Kwiatkowski, Jacek (2002): The State of Democracy in Poland's Gminas. In Gabor, Soós - Gabor, Tóka - Wright, Glen (ed): The State of Local Democracy in Central Europe. Local Government and Public Service Reform Initiative. Open Society Institute, Budapest, 185-284.

Pajas, Petr (1997): Czech Republic. In The New Civic Atlas. Profiles of Civil Society in 60 Countries. Civicus, Washington, D. C. 33-34

Pánovics, Attila (2015): A civil szervezetek szerepe. In. Gajdics Ágnes - Szilágyi Szilvia. (ed.): A magyar környezetvédelmi jog 20 éve: Összefoglaló az EMLA 2014. december 8-án tartott ünnepi közgyűléséről. 30 p. Konferencia helye, ideje: Magyarország, 2014. 12. 08 Budapest: EMLA Környezeti Management és Jog Egyesület. 24-25.

Pospíšil, Miroslav - Prouzová, Zuzana - Škarabelová, Simona - Tůmová, Kateřina Almani (2012): A cseh nonprofit szektor húsz év után: aktuális fejlemények kihívások. Civil Szemle, IX. éfv. 3. Sz. 23-41.

Pop, Luana (2002): Autonomy of Local Government Administration in Romania. In Soós, Gábor - Tóka, Gábor - Wright, Glen (ed.): The State of Local Democracy in Central Europe. Local Government and Public Service Reform Initiative. Open Society Institute, Budapest. 332-340.

Przewłocka, Przewłocka - Herbst, Jan - Gumkowska, Marta (2012): A lengyel harmadik szektor áttekintés, kulcstényezők, tendenciák és kihívások. Civil Szemle, IX. Évf. 3. sz. 59-73.

Salamon, Lester M. - Anheier, Helmut K. (1998) Social Origins of Civil Society. Voluntas: International Journal of Voluntary and Nonprofit Organisations 9 (3): 213-248.

Salamon, Lester M. - Sokolowski, Wojciech S. - Anheier, Helmut K. (2000): Social Origins of Civil Society: An Overview. Baltimore: Center for Civil Society Studies.

Sárközy, Tamás (2014): Kétharmados túlkormányzás. Park Könyvkiadó, Budapest. 
Sárközi, Tamás (2019): Illiberális kormányzás a liberális Európai Unióban. Politikailag igen sikeres túlhajtott plebejus kormányzás. A harmadik Orbán-kormány 2014-2018. Park Könyvkiadó, Budapest.

Seligman, Adam B. (1992), Érvek a „civil társadalom” ellen. Szociológiai Szemle, 1992/1.

Strečanský, Boris (2012): A szlovákiai harmadik szektor helyzete, a válság hatásai, tendenciák, irányvonalak és kivívások. Civil Szemle, IX. Évf. 3. sz. 95-114.

Torma, Judit (2016): A norvég-ügy - Civil szervezetek elleni kormányzati támadássorozat Magyarországon (2013 és 2016). In Antal, Attila (ed.): A civilek hatalma - A politikai tér visszafoglalása. Budapest, Noran Libro Kiadó, 266-281.

Vörös, Zoltán (2016): Directions for development of political systems - decrease in legitimacy. In: Beata, Pająk-Patkowska; Marcin, Rachwał (ed.) Hungary and Poland in Times of Political Transition. Selected Issues. Poznan, Adam Mickiewicz University Press. 25-38.

László Kákai been professor of Political Sciences at the Department of Political Studies of the Faculty of Humanities of the University of Pécs since 1997. He is Head of the Department Political Science and International Studies at the University of Pécs, and from 2012, president of the Community Environment College of the National Cooperation Fund. His main research interest is local politics, local government and civil society.Email:kakai.laszlo@pte.hu 